\title{
Device associated nosocomial infections in a medical intensive care unit of a tertiary care hospital in Jaipur, India
}

\author{
S Sood ${ }^{1 *}$, SH Joad $^{2}$, D Yaduvanshi ${ }^{3}$, P Anand ${ }^{2}$ \\ From International Conference on Prevention \& Infection Control (ICPIC 2011) \\ Geneva, Switzerland. 29 June - 2 July 2011
}

\section{Introduction / objectives}

Intensive care units (ICUs) are unfortunately the epicenters of nosocomial infections. Limited data is available regarding burden of healthcare associated infections (HAIs) in Indian ICUs, especially the rates of device associated infections by using standardized definitions.

\section{Methods}

We conducted a prospective surveillance of device associated infections from January 2010-December 2010 in a 10 beded Medical ICU of Fortis Escorts Hospital, Jaipur. CDC-NNIS system definitions for all device associated infections were used and rates were calculated per 1000 device days. Device utilization ratio was calculated by dividing the total number of specific device days by the total number of patient days. Microbiological profile of each HAI was noted.

\section{Results}

435 patients were admitted in the Medical ICU representing 3080 patient days. The overall DANI (device associated nosocomial infection) rate was $4.36 \%$ (19/ $435)$ or $6.16(19 / 3080)$ DAI per 1000 ICU days. The overall VAP rate was 8.9 infections per 1000 ventilator days, CLABSI rate was 2.74 infections per 1000 central day and CAUTI rate was 1.50 infections per 1000 catheter days. Device utilization ratio for central line, ventilator and urinary catheter was $0.59,0.36$ and 0.86 respectively. Non fermenters Gram negative bacteria accounted for $73.68 \%$ infections followed by Enterobacteriaceae $(21.05 \%)$. The most common bacteria were Acinetobacter baumannii (26.31\% of total) and

${ }^{1}$ Super Religare Laboratories, Fortis Escorts Hospital, Jaipur, India

Full list of author information is available at the end of the article
Pseudomonas aeruginosa and Klebseilla pneumoniae (10.52\% of total each).

\section{Conclusion}

Targeted surveillance and calculation of device associated infection rates per 1000 device days allows detection of unique institutional problems that need redress.

\section{Disclosure of interest}

None declared.

\section{Author details}

${ }^{1}$ Super Religare Laboratories, Fortis Escorts Hospital, Jaipur, India. ${ }^{2}$ Critical Care Medicine, Fortis Escorts Hospital, Jaipur, India. ${ }^{3}$ Pulmonary Medicine, Fortis Escorts Hospital, Jaipur, India.

Published: 29 June 2011

doi:10.1186/1753-6561-5-S6-O16

Cite this article as: Sood et al:: Device associated nosocomial infections in a medical intensive care unit of a tertiary care hospital in Jaipur, India. BMC Proceedings 2011 5(Suppl 6):016.

Submit your next manuscript to BioMed Central and take full advantage of:

- Convenient online submission

- Thorough peer review

- No space constraints or color figure charges

- Immediate publication on acceptance

- Inclusion in PubMed, CAS, Scopus and Google Scholar

- Research which is freely available for redistribution 